\title{
Junior High School Students' Difficulties of English Language Learning in the Speaking and Listening Section
}

\author{
Alan Jaelani ${ }^{1}$, Olivia Widad Zabidi ${ }^{2 凶}$
}

English Department, Faculty of Teacher Training and Education, Universitas Ibn khaldun, Indonesia

\begin{tabular}{l} 
Article Info \\
\hline Article History: \\
Received in 13 April \\
2020 \\
Approved in 1 July 2020 \\
Published in 30 July \\
2020 \\
\\
\hline Keywords: English \\
Education; Difficulties \\
Learning; English \\
Speaking; English \\
Listening; English \\
Learning Strategies. \\
\hline
\end{tabular}

\begin{abstract}
This study aims to determine students' problems in learning English, especially in terms of speaking and listening. Basically, the teaching and learning process will run smoothly if students feel comfortable with the learning activities; therefore, this research provides some appropriate suggestions for teachers in overcoming difficulties faced by students. The respondents of this study were junior high school students. This study used a questionnaire as an instrument to determine the extent of students' skills in English. This study also conducted data analysis by analyzing the importance of English in students' views, the difficulties encountered in learning English, and also the teacher's teaching strategies desired by students. The results of this study indicate that most students have some difficulties in speaking due to lack of confidence and skills such as pronunciation, vocabulary, and grammar. Likewise, the difficulty in listening is caused by students' lack of vocabulary that leads to the difficulty in understanding conversations in English. To overcome this problem, teachers need to have strategies such as identification, diagnosis, prognosis, and assistance or therapy. This research can facilitate the teachers in knowing complaints about English language difficulties experienced by the students.
\end{abstract}

\footnotetext{
${ }^{\square}$ Correspondent Address: p-ISSN 2252-6706 | e-ISSN 2721-4532

KH. Sholeh Iskandar Km. 2 Street, Kedung Badak

Sekaran, Gunungpati, Semarang, 50229

E-mail: $\underline{\text { author@gmail.com }}$
} 


\section{INTRODUCTION}

Language is a tool of communication that is very instrumental in daily life. Because of language we can exchange information and ideas with others and express the feelings, desires, opinions and needs of each individual. Human's life cannot be separated from language activities. Language is a means to communicate between humans. In line with the development of science and technology humans are required to have good language skills. Someone who has adequate language skills will be easier to absorb and convey information both spoken and written. This skill is not a type of skill that can be passed down for generations though basically naturally every human being can talk. However, speaking and listening skills basically require intensive training.

Thus, English subjects are really needed for every level of education. Language learning lessons in schools are expected to not only focus on theory, but students are also required to be able to use language as a function, namely as a tool for communication. According to Yamin (2017), teaching is not just about delivering subject matter, but teaching is the process of changing student behavior in accordance with expected goals. Therefore, a teacher needs to have the ability to design and implement a variety of learning strategies that are considered in accordance with interests and talents and in accordance with the level of student development. According to Pane \& Dasopang (2013, p.333), learning and learning are two things that are closely interrelated and inseparable in educational activities, learning and learning are said to be a form of education that makes an interaction between teacher and student. Learning and learning take place in a process that begins with planning various components and learning tools so that they can be implemented in the form of educational interactions, and ends with an evaluation to measure and assess the level of achievement of the learning objectives expected by Hanafy (2014, p.67).

Along with the times, this world has set one language as an international language, namely English. Therefore, learning English is very important, because English is an international language that is generally used as a language of communication for people who come from abroad. Hawkes \& Schechter $(2016$, p.3) quoted that due to the importance of mastering foreign languages, German philosopher Johann Wolfgang Von said "Those who know nothing about foreign languages, they have nothing about their own." This saying implies that how important is the education of foreign languages besides mother tongue and national languages. Handayani (2015, p.104) states that English is not only an academic need because its mastery is not only limited to aspects of language knowledge but also as a medium of global communication, especially in terms of the economy. In this case ASEAN is one of the gateways to the global economy, where industries and business activities in the ASEAN region are key and major players in the supply chain and production network, both globally and regionally. In connection with that, according to Megawati (2016), mastery of international language skills are things that need to be developed at this time because with the appointment of Indonesia as a member of the MEA (ASEAN Economic Community), it is fitting for a more advanced generation of the nation in terms of science and technology supported by the mastery of good and correct language of instruction. In addition, English in Indonesia has also developed into an intellectual and social media of self-image, for example young people are currently using English in their daily activities. This relates to statement by Ningsih $(2019$, p.6) which states that currently English has been successfully accepted and accepted by the Indonesian people especially millennial generation. Many found in social media the use of English is more prominent when compared to the use of Indonesian itself.

Basically, according to Megawati (2016, p.148) English has three additional abilities, namely Grammar, Vocabulary and Pronunciation, all of these components are very important for improving optimal English language skills. In addition, mastery of the material and practice must also be given a balanced portion. Improvement of English language skills in the people of Indonesia can be realized by holding language classes, both formally and informally. Widyasari (2016, p.31) argues that the importance of the role of English in the learning and teaching process requires an appropriate method to improve students' English proficiency with learning activities that are fun and attractive to students. According to the authors this can happen because not all Indonesian people enjoy enjoying learning a new language, therefore if all learning conditions are generalized it will be difficult to achieve the expected learning goals, because basically every student has different characteristics including learning techniques and portions absorption of matter. This is in line with the statement of Suherman \& Yustiana $(2017$, p.6) which states that with the many factors involved in the learning process, not all individuals have the ability to overcome problems related to learning activities. In this case, teaching strategies by way of identification, diagnosis, prognosis, and providing assistance or 
therapy were considered quite effective. With the aim of being able to treat each student with proper care, the English learning method plays a very important role in English learning activities. There are many students who are able to achieve good performance because they are taught using the English learning method correctly. Fun English learning methods are the key to learning Yamin (2017, p.84).

Meanwhile, according to Mistar (2014, p.204) there are several factors that are considered influential on the assessment of skills, such as achievement in school, attitudes toward English speaking, tasks completed, and also topics that delivered by teachers. In fact, not a few students are still unable to understand the sentence that spoken in English verbally by the interlocutor. This means that their English skills are still lacking and their vocabulary is still very limited. Speaking skills are productive skills that can be directly observed. According to Siska (2011, p.3) speaking is a language skill that develops in the life of someone who is preceded by listening skills, in that time speaking ability is learned. Speaking is closely related to the development of vocabulary that is obtained by someone through listening and reading activities. However, formal speaking skills require intensive training and direction. As according to Wallace, et al (2004, p.13) write that listening skills are very important skills because these can make humans gain insight, understanding knowledge and information, and achieve success in communicating with others.

Therefore, speaking and listening skills are two very important things in language. However, listening is not a simple process. Someone who listens must distinguish between sounds and understand vocabulary also grammatical structures, remember and interpret them all at the same time. Likewise, according to Harmer (2013, p.269) which describes the ability to speak fluently not only rely on knowledge of language features, but also the ability to process information and language. In the process of English learning, a student certainly has experience an obstacle in learning. These obstacles can cause the maximum lack of student learning outcomes. Of the problems that faced are certainly encouraging a teacher or language instructor to pay more attention to the conditions of their students followed by readiness in the implementation of learning. By understanding the problems faced students, an educator can do self-reflection to find out how much effective implementation of the learning process in the classroom and to improve student quality.

Previous research related to this article is "Students' Difficulties in Speaking English at the Tenth Grade of Vocational High Schools" studied by Catur Widyasworo (2019). This study uses descriptive qualitative data methods that aim to find out the factors that influence students 'difficulty in speaking English, researchers also conduct research on the scores of these students and the results of this study indicate that the average score of students' speaking skills is 64.8. That includes enough categories. The difficulty of speaking students is discussed in the category of linguistic and non-linguistic problems.

The second study related to this article is a study entitled " Study of the factors that cause learning difficulties of English Listening in PBI IAIN students Raden Intan Lampung in the academic year 2015/2016." researched by Dewi Kurniawati (2015). This study uses descriptive qualitative data methods that aim to find out the factors that influence students' difficulty in listening to English. This study focuses on the difficulty of students in learning English listening, this study shows that the average student has difficulty listening because of internal factors such as fatigue so students become less focused.

Based on the concepts presented above, it can be concluded that there are many difficulties faced by students when learning English. The two reference articles above only focus on one of the difficulties of Listening or Speaking. Therefore, in this article the author is interested in digging deeper into the obstacles experienced by students in the four language skills related to Speaking and Listening simultaneously. According to the authors, this research is important because through this research the teachers can find out what difficulties and obstacles are experienced by students while learning to listening and speaking in English, if that's the benefit gained from this research.

\section{METHODS}

This study employed the descriptive qualitative method which involved 20 students from two schools in Bogor and focuses on the difficulties faced by students during the learning English process in class. The researcher wants to find the right solution for the problems faced by students, therefore the researcher conducts this study. In this regard, the notion of qualitative research itself is study that is descriptive in nature and tends to use analysis, processes and meanings highlighted in qualitative research, the theoretical basis is also used as a guide so that the focus of research is in accordance with facts on the ground. 
According to Rahmat $(2009$, p.2), one of the reasons for using qualitative methods in a study is because this method can be used to find and understand what is hidden behind phenomena that are sometimes difficult to clearly understand. While descriptive research is study that involves description, recording, analysis, and interpretation of existing conditions. The purpose of descriptive research is to describe the facts and characteristics of the object or subject being studied systematically. The data used in this study is qualitative data. This research needs some data to be analyzed.

Thus, this study uses data retrieval by providing instruments that have two types of questions such as; open-ended questionnaire as explained by Dwinawan (2018) that open-ended question is a type of question that is used to get broad answers, this is intended so that researchers obtain clearer data, and also make it easier for respondents to answer it. This type of question has been asked by the author to respondents by giving questions that are similar in nature to essays, where respondents can freely give answers without the need to be stunned by the choices of answers that have been provided by the author. The second type of question is the closed-ended question as explained by Lidiana (2011) that close-ended question is a type of question that requires a more specific answer, this type of question makes it easy for the interviewer to control the sources and get the information they need. This type of question has been asked by the author to respondents by giving questions that are similar in nature to multiple choice in which the respondents do not have the opportunity to write their own responses but have been provided choices by the author. This type of question limits the person being asked because it is only possible to choose one of two choices such as; yes or no, true or false, agree or disagree.

Based on these explanations, the researcher gave some closed ended questions in which respondents could choose one of the three answer options prepared, this type of question is used to convince researchers of the answers to which options have a bigger percentage. In addition, the researcher also gave an open ended question in which the respondents were entitled to give their opinion in the blank answers column that have provided, this type of question was quite helpful in the process of identifying data because the researcher could find out the wishes of the respondents in accordance with the opinions they gave.

After successfully collecting data based on the questionnaire used, the researcher began to analyze the data to determine the results of this study then analyzing by using analytical techniques consisting of data identification, followed by the process of data tabulating, then calculating the data by totaling and then changing to percent form. This method is used to find out in detail about the results of this study, the number of percentages in a study is important to include. According to Hidayat (2019), in research, the percentage results are important things that are used to generalize the results of a study. Indeed this is not a mandatory requirement in a study that uses qualitative data methods, but if a study does not use this calculation technique, then the research cannot be drawn to broader conclusions. The results of the study are limited to research objects that are limited in time and place of research. Therefore, research like this is still needed.

\section{FINDINGS AND DISCUSSION}

This section explains the result of the questionnaire given. It consists of two stages, namely the stage of finding and discussion stage.

\section{Findings}

Finding will explain the results of observations about the difficulties faced by students in learning English, and of course using a predetermined instrument that is a questionnaire. While the discussion is used to find out and explain the right steps to overcome the problems contained in the finding section. Below, the results of the questionnaire which used close ended question will be presented in the form of diagrams. 


\section{Diagram 1 \\ Students' Interest in English Language Learnir}



Diagram 2

The Importance of English in Students' Views

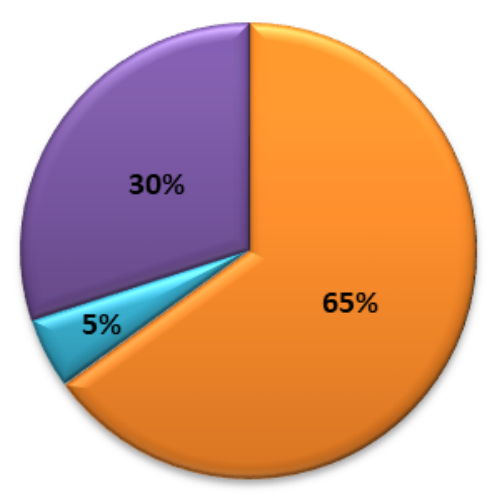

$\square$ Important

$\square$ Unimportant

Maybe

The author tries to explore how much interest students have in learning English and also find out how important English learning is to them. This is because that apart from the teacher factor, motivation within students is also very influential in the development of language skills. According to Harahap \& Syarifah (2015, p.22) students who like and consider English important will be easy for them to understand and master English. Therefore, based on diagrams 1 and 2 above, it is known that most of the SMP / MTS students consider that English is a compulsory subject that is important to learn, even most of them are also students who like English subjects. Behind it all, of course there are things that become obstacles in the learning process, namely the difficulties experienced by these students. 


\section{Diagram 3 \\ Students' Difficulties in English Language Learning}

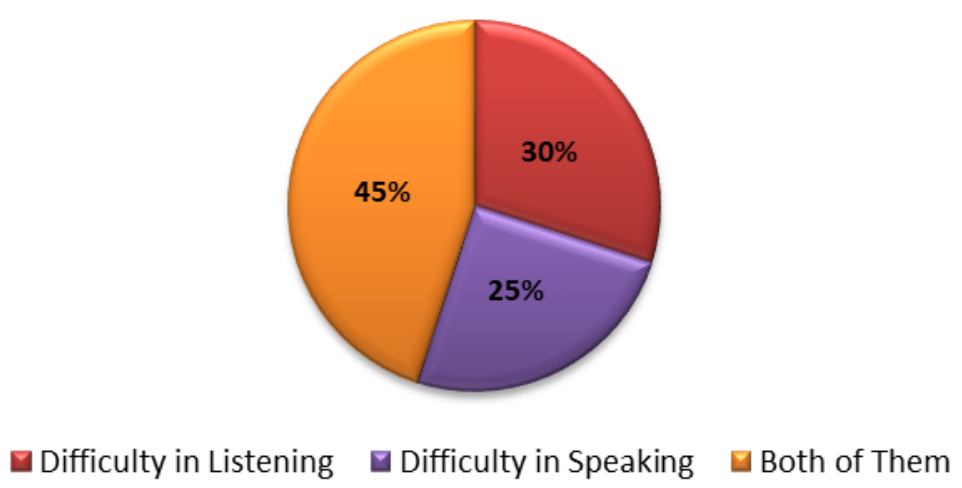

In diagram 3 , it has been noted that most students have difficulty in listening and speaking. As stated by Hasan (2000), the difficulty faced by many English language learners as a foreign language is the lack of understanding of English pronunciation expressed at normal speed through listening material. The next statement from Megawati \& Mandarani (2016) found that the difficulty students often face when speaking English lies in the lack of English vocabulary. In this regard, the authors have examined the factors that make students feel difficulty in learning English, the results will be seen in diagrams 4 and 5 below.
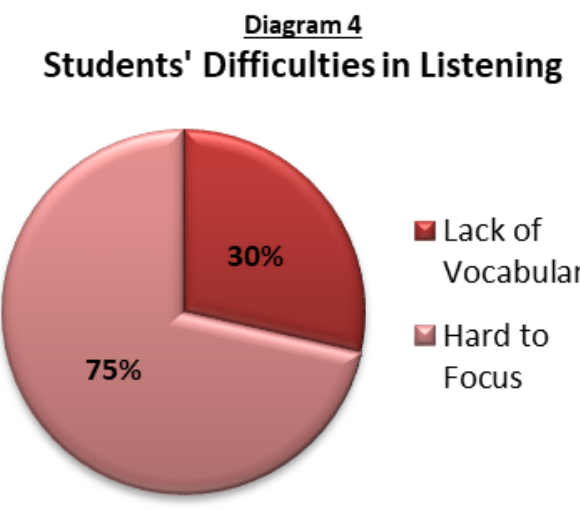

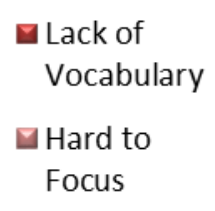

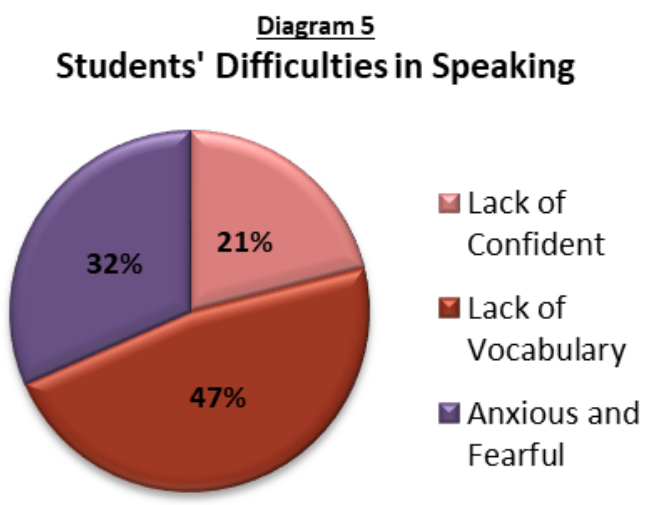

Seeing from these difficulties, researchers also took the initiative to ask about the teacher's strategy what they want in the teaching and learning process. Here, researchers use open-ended questions to explore more information related to the things desired by respondents, because in this part of the question respondents can answer anything in accordance with their opinions and desires of each. This is in line with the statement of Nohda $(2000$, p.41) with the existence of open-ended questions, the teacher has the opportunity to help students understand and elaborate ideas or learning strategies desired by students as far and as deep as possible.

\begin{tabular}{clc}
\hline No & \multicolumn{1}{c}{ Answer of 20 Respondents } & Percentage \\
\hline 1 & $\begin{array}{l}\text { Students wants the teacher to continue to } \\
\text { provide exercises and tests to students }\end{array}$ & $45.0 \%$ \\
2 & $\begin{array}{l}\text { Students want the teacher to continue to } \\
\text { motivate students and educate patiently }\end{array}$ & $30.0 \%$ \\
3 & $\begin{array}{l}\text { Students wants the teacher to explain in detail } \\
\text { and not rush in providing material }\end{array}$ & $25.0 \%$ \\
\hline
\end{tabular}


For this last question, this is a close-ended type of question because the author wants to infer about how persistent their efforts are in learning English. As quoted by Reja et al. (2003, p.159) Close-ended questions in general yield higher percentages than open-ended questions for answers that are identical in both question forms. Therefore, the following will be seen in diagram 6 .

\title{
Diagram 6 \\ The Decision of Students In Learning English with Difficulties Encountered
}



\author{
Give up and choose \\ to study other \\ subjects \\ $\square$ Keep learning even \\ though it's hard
}

In diagram 6, it is seen that the majority of respondents choose to continue to struggle in overcoming the difficulties they faced, this thing of course can facilitate teachers in implementing specific teaching strategies because what is most important in a learning is strong desire and determination.

\section{Discussion}

After successfully collecting the data by means of a survey and using a questionnaire instrument, here will be explained in detail about the responses of students in the questionnaire form that researchers made.

The first is the interested and importance of English in the students' view, after seeing the results of some of the diagrams above, it appears that English is an important subject and of course most students are interested in learning English in this modern era. This of course becomes a very important supporting factor in developing language skills for students, as said by Baker (1992, p.205) that the problem of students' attitudes is recognized as one of the most important factors affecting language learning. Therefore, with the results of research that show that most students behave well in looking at the importance of English then it is also a good start in the learning process.

The second is the difficulties experienced by student, of course in learning something, we will face some or maybe many difficulties. According to Ahmadi \& Supriyono (1991, p.88) states that learning difficulties are a condition of the learning process marked by certain obstacles to achieving learning outcomes. An example is the difficulty experienced by students in listening and speaking in English. From these two aspects, first aspect is listening that based on the survey results, it appears that most students have difficulty in speaking due to lack of vocabulary mastery, while the average assignment given in the listening section is related to audio / video that contains conversations. Therefore, the lack of mastery of vocabulary is certainly very influential on the smooth learning process of English subjects themselves.

This is in line with Wilson (2008, p.12) which groups the factors causing students' difficulty in listening into three general groups namely; (1) Characteristics of the message where the message delivered contains difficult words and grammar, the listener's ignorance of the topic being discussed, as well as its rapid delivery, will 'force' the listener to concentrate fully on listening to the message. These factors are one of the causes of difficulty in listening; (2) Characteristics of message delivery, regarding whether the message delivered by reciprocal listening or non-reciprocal listening. Reciprocal listening is an interaction that occurs by involving two or more people as in a conversation. On this occasion the listener can react, ask questions or ask for clarification to people who convey the message if they feel something is confusing. On other occasions they can ask people 
who speak to be able to speak slowly and clearly so that what they say can be understood. Whereas the non-reciprocal listening listener cannot control the speaker, or to find out whether the message received is correct or wrong. For example when listening to radio broadcasts, announcements, watching TV and so on. That is why non-reciprocal listening is considered more difficult than reciprocal listening; (3) Characteristics of message recipients or listeners, individual differences cause the same message to be understood differently. This happens because of differences in motivation, age, ability to concentrate for a long time, physical conditions and so on, for example for people who are physically weak may have to listen to a message over and over again, while for oaring whose physical condition is good, it may only require one delivery only.

The next aspect is Speaking, in the speaking section, most students find it difficult because of internal factors, namely feeling anxious and afraid of incorrect pronunciation. This is of course related to external factors such as; do not have good pronunciation, lack vocabulary, and do not master grammar. This is in line with the statement of Sari \& Lestari (2009, p.445) which revealed that speaking difficulties are usually caused by several factors such as; a) Difficult to express ideas verbally; b) Limited vocabulary, so it often stops suddenly while talking; c) Limited grammar ability, so it is difficult to speak with the correct rules; d) Limited pronunciation, so it is difficult to pronounce the words spoken correctly and make the listener confused with his words; e) Lack of courage to speak out of fear of being wrong.

The third is teacher strategies desired by students, based on the survey results, there were answers from 20 respondents about how to teach the teacher wanted by students. In overcoming the difficulties faced by these students, it is known that as much as $25 \%$ of students want the teacher to explain in detail and not rush in providing material, as much as $30 \%$ of students want the teacher to continue to motivate students and educate patiently, and as much as $45 \%$ of students want the teacher to continue to provide exercises and tests to students. This shows that students actually understand that the key to success in English is to continue to train themselves.

However, often students feel pressured by English tests. Apart from lack of skills, they also often feel discouraged when making mistakes, this usually happens because the environment is less supportive. For example, when student A ventured to speak English in front of his classmates but he made a mistake, it was not uncommon for student $\mathrm{A}$ to be laughed at by his classmates. So far, the biggest factor in hindering the process of learning English is anxiety and fear of making mistakes due to lack of skills. This is of course related to the teaching and learning process of listening and speaking. This is a challenge for teachers to be able to overcome the difficulties faced by students. Because according to Inayah $(2017$, p.4) the success of the teaching process can be achieved if the teacher can present the material well and can increase student interest. Munirah (2018, p.15 \& 16) has delivered a number of tricks such as identification, diagnosis, prognosis, and assistance / therapy which are considered effective in overcoming these difficulties.

Identification is an activity directed to look for students who have learning difficulties, i.e. seek information about these students. According to Lubis (2018, p.30) identifying initial behavior and characteristics of students in the development of learning programs is very necessary to determine the quality of individuals so that it can be used as a guide in describing learning management strategies.

Diagnosis is the determination of the results of data processing about students who have learning difficulties and the types of learning difficulties experienced by students. As according to Yunita (2016, p.9) diagnosis is the process of determining the location of weaknesses or abnormalities by examining and analyzing the background or causal factors as well as symptoms of problems that appear with the aim of drawing conclusions and looking for alternative solutions.

Prognosis is an activity that refers to the activity of preparing a plan or program that is expected to help overcome the problem of student learning difficulties. Kemala (2015, p.18) states that this step is carried out to estimate whether the problems experienced by students are still possible to be overcome and determine various alternative solutions, this is done by integrating and interpreting the results of the second and third steps.

Kumalasari (2017, p.16) said that the problem of students' self-confident can pose major obstacles in the areas of social life, learning and career. Students who have low self-confidence (hard to adjust themselves) in their personal lives are filled with doubts to determine an action or are often anxious and like to be alone and stay away from the environment. The therapy referred to here is to provide assistance to children who have learning difficulties like that, assisted in accordance with the program that has been prepared at the prognosis stage. 


\section{CONCLUSION}

Based on data analysis and data interpretation, the conclusion is that this study uses descriptive qualitative data methods that aim to find out the factors that influence students' difficulties in listening to English and use qualitative descriptive methods involving 20 students from two schools in Bogor. Based on the survey results, most of the students at Bogor Junior High School are students who like English, they also understand the importance of English in the modern era, this is a pretty good supporting factor for the development of students' English skills. This research also found that many of them had difficulty in listening and speaking due to lack of mastery of vocabulary and lack of confidence to dare to practice directly about the knowledge they had acquired. In overcoming this problem, the strategy undertaken by the teacher is by way of identification, diagnosis, prognosis, and providing assistance or therapy. Based on these results it can be concluded that it is important for English teachers to teach using a variety of specific strategies as described above, because this is useful to overcome the difficulties faced by students for the smooth teaching-learning process. Besides because English is a subject that must be mastered because it will be found on the National Examination, English will also make it easier for us to communicate with people from abroad because English itself has been established as an international language. For this reason, it is important for students to acquire and have good English skills.

\section{REFERENCES}

Ahmadi, H. A., \& Supriyono, W. (1991). Psikologi belajar. Rineka Cipta.

Asworo, C. W. (2019). The Analysis of Students' Difficulties In Speaking English at the Tenth Grade of SMK N 2 Purworejo. Journal of English Education and Teaching, 3(4), 533-538.

Baker, Colin. (1992). Attitudes and Language. Clevedon: Multilingual Matters.

Damayanti, M., \& Maharani, A. (2011). Kebutuhan Penguasaan Bahasa Asing pada Mahasiswa Universitas Paramadina dalam Era Globalisasi. Masyarakat, Kebudayaan, dan Politik, 24(3), 272279.

Dwinawan. (2018). Mengenal Open-Ended dan Close-Ended Questions dalam User Interview. Medium. Retrieved from https://medium.com/insightdesign/mengenal-open-ended-danclosed-ended-questions-dalam-user-interview-1b163ff874a.

Hanafy, M. S. (2014). Konsep Belajar dan Pembelajaran. Lentera Pendidikan: Jurnal Ilmu Tarbiyah dan Keguruan, 17(1), 66-79.

Handayani, S. (2016). Pentingnya Kemampuan Berbahasa Inggris Sebagai Dalam Menyongsong ASEAN Community 2015. Jurnal Profesi Pendidik, 3(1), 102-106.

Harahap, D. H., \& Syarifah, R. (2017). Studi kasus kesulitan belajar matematika pada remaja. Jurnal Psikologi, 11(1).

Harmer J. (1991). The Practice of English Language Teaching. London: Longman Group U.K.Limited.

Hasan, A. S. (2000). Learners' perceptions of listening comprehension problems. Language Culture and Curriculum, 13(2), 137-153.

Hawkes, R., \& Schechter, S. (2016). Leadership and languages: inspiring young linguists. Employability for languages: a handbook, 171-180.

Hidayat, A. (2019). Manfaat Analisis Hasil Penelitian. Globalstats Academic. Retrieved from https://www.globalstatistik.com/manfaat- analisis-hasil-penelitian/.

Inayah, R., \& Lisdawati, I. (2017). Exploring Studentsâ€ $\mathrm{EM}^{\mathrm{TM}}$ Difficulties in Speaking English and Their Attitude In Speaking English. Acuity: Journal of English Language Pedagogy, Literature and Culture, 2(1), 12-23.

Kemala, B. (2015). Kinerja Guru Pembimbing dalam Mengatasi Kesulitan Belajar Siswa SMP Negeri Banda Aceh. [Thesis, Universitas Syiah Kuala]. ETD Unsyiah.

Kurniawati, D. (2015). Studi Tentang Faktor-Faktor Penyebab Kesulitan Belajar Menyimak Bahasa Inggris Pada Mahasiswa Semester III PBI IAIN Raden Intan Lampung Tahun Pelajaran 2015/2016. English Education: Jurnal Tadris Bahasa Inggris, 8(1), 157-178.

Lidiana, E. (2011). Interview Method. Blogspot.com. Retrieved from http://evimursalim.blogspot.com/2011/01/interview.html.

Megawati, F. (2016). Kesulitan mahasiswa dalam mencapai pembelajaran bahasa Inggris secara efektif. PEDAGOGIA: Jurnal pendidikan, 5(2), 147-156.

Megawati, F., \& Mandarani, V. (2016). Speaking Problems in English Communication. [Proceeding ELTic Conference 2016]. Universitas Muhammadiyah Sidoarjo. 
Mistar, J., \& Umamah, A. (2014). Strategies of learning speaking skill by Indonesian Learners of English and Their Contribution to Speaking Proficiency. TEFLIN Journal, 25(2), 203-216.

Munirah, M. (2018). Peranan Guru dalam Mengatasi Kesulitan Belajar Siswa. TARBAWI: Jurnal Pendidikan Agama Islam, 3(02), 111-127.

Ningsih, A. N. M. (2019). Penggunaan Bahasa Indonesia dan Bahasa Inggris dalam Menunjang Ilmu Pengetahuan di Era Global. Solo: Universitas Sebelas Maret.

Nohda, N. (2000). Learning and teaching through open-ended approacrh method. Dalam Tadao Nakahara dan Masataka Koyama. Proceeding of the 24th of the Intenational Group for the Psychology of Mathematics Education. Hiroshima: Hiroshima University.

Pane, A., \& Dasopang, M. D. (2017). Belajar dan pembelajaran. Fitrah: Jurnal Kajian Ilmu-ilmu Keislaman, 3(2), 333-352.

Pupu, S. R. (2009). Penelitian Kualitatif. Jurnal Eqiulibrum, 5(9).

Reja, U., Manfreda, K. L., Hlebec, V., \& Vehovar, V. (2003). Open-ended vs. close-ended questions in web questionnaires. Developments in applied statistics, 19(1), 159-177.

Sari, L., \& Lestari, Z. (2019). Meningkatkan Kemampuan Berbicara Bahasa Inggris Siswa dalam Menghadapi Era Revolusi 4.0. In Prosiding Seminar Nasional Program Pascasarjana Universitas PGRI Palembang, Vol. 12, (01).

Siska, Y. (2011). Penerapan Metode Bermain Peran (Role Playing) dalam Meningkatkan Keterampilan Sosial dan Keterampilan Berbicara Anak Usia Dini. J. Educ, 1(1).

Wallace, T., Stariha, W. E., \& Walberg, H. J. (2004). Teaching speaking, listening and writing. International Academy of Education.

Widyasari, F. E. (2016). Pembelajaran Bahasa Inggris Dengan Menggunakan Metode Multiple Intelligences: Studi Kasus Di Sekolah Internasional. Jurnal Pendidikan Edutama, 3(1), 31-45.

Yamin, M. (2017). Metode Pembelajaran Bahasa Inggris di Tingkat DAS. Jurnal Pesona Dasar, 1(1).

Yunita, W. (2016). Diagnosis dan Upaya Mengatasi Kesulitan Belajar Matematika dengan Induced Fit Remedial Teaching Strategy dengan Pendekatan Participative Learning [Doctoral dissertation, Universitas Negeri Semarang]. 